\title{
DNA concentration and length in sputum of patients with cystic fibrosis during inhalation with recombinant human DNase
}

\author{
Tanja Brandt, Stefanie Breitenstein, Horst von der Hardt, Burkhard Tümmler
}

\begin{abstract}
Background - The clinical benefit of the administration of aerosolised recombinant human DNase (rhDNase) on pulmonary function in patients with cystic fibrosis has already been demonstrated but the biochemical action of rhDNase on DNA in bronchial secretions in vivo has not yet been investigated.

Methods - Sputum was collected from 135 patients with cystic fibrosis before and during treatment with aerosolised rhDNase and examined to ascertain DNA concentration and length by colorimetric assay and densitometry of gel separated DNA.

Results - Treatment with rhDNase reduced the concentration and the size of extracellular DNA in the sputum. The median interquartile range of DNA length decreased from $0.5-2.6 \mathrm{kbp}$ before treatment to $0 \cdot 3-1 \cdot 0 \mathrm{kbp}$ during treatment.

Conclusions - rhDNase was delivered to the secretions and was enzymatically active in vivo.
\end{abstract}

(Thorax 1995;50:880-882)

Keywords: DNase, cystic fibrosis, sputum analysis.

Respiratory tract disease characterised by the accumulation of mucopurulent secretions and chronic endobronchial infection is responsible for more than $90 \%$ of the morbidity and mortality in cystic fibrosis. ${ }^{1}$ On the basis of the hypothesis that an increased concentration of high molecular weight DNA contributes to the abnormal viscoelastic properties of sputum and airway obstruction, recombinant human deoxyribonuclease I (rhDNase) has been delivered as an aerosol to the airways of patients with cystic fibrosis. ${ }^{2-7}$ The administration of rhDNase reduced but did not eliminate exacerbations of respiratory symptoms ${ }^{7}$ and resulted in a slight improvement in pulmonary function. ${ }^{3-7}$ Although the clinical benefit of aerosolised rhDNase has been demonstrated in several trials, ${ }^{3-7}$ the biochemical action of rhDNase on its substrate in vivo has not yet been investigated. We measured the concentration and length of DNA in sputum samples from patients with cystic fibrosis collected before and during treatment with aerosolised rhDNase.

\section{Methods}

One hundred and thirty five patients with cystic fibrosis from seven German cystic fibrosis outpatient clinics participated in a 12 week phase III trial on the inhalation of $2.5 \mathrm{mg}$ rhDNase (Pulmozyme, Genentech Inc, San Francisco, USA) once daily. Criteria for study entry were no indications for hospital admission and a forced vital capacity of $40-70 \%$ predicted.

Sputum expectorated during physiotherapy was collected on three consecutive days directly before the first inhalation of rhDNase and again on three consecutive days after six weeks of inhalation of rhDNase. Sputum containers were stored in the refrigerator and at the end of each sampling period the three sputum containers were brought to the Hannover laboratory, frozen to $-20^{\circ} \mathrm{C}$ upon arrival, and stored for up to six weeks. Thawed sputum was liquified for 3-5 hours at room temperature under stirring with a twofold volume of $2 \%(\mathrm{v} / \mathrm{v})$ aqueous mercaptoethanol. Cells and debris were spun down by centrifugation at $1200 \mathrm{~g}$ for 10 minutes. Supernatants from each patient's three day collection period were pooled and lyophilised, with the exception of the 63 pretreatment and 72 treatment samples from the 25 patients of the Hannover cystic fibrosis clinic which were analysed on a day-to-day basis. The freeze dried sample was reconstituted in distilled water and the DNA concentration was then determined by colorimetric assay with diphenylamine according to the method of Burton $^{8}$ modified by Croft and Lubran ${ }^{9}$ using human blood cell DNA as standard. To determine the DNA length, DNA was isolated ${ }^{10}$ from lyophilised samples by digestion with proteinase $\mathrm{K}$, extractions with phenol/chloroform, precipitation with ethanol, and dissolution in $10 \mathrm{mM}$ Tris/HCl, $1 \mathrm{mM}$ EDTA, pH 8.0. The purified DNA was separated by $1 \%$ agarose gel electrophoresis using a $\lambda$-BstEII digest as a size marker. The size distribution was measured by laser densitometry of $8.5 \times 10.8 \mathrm{~cm}$ Polaroid negative films of the ethidium bromide-stained agarose gel. 
Median (interquartiles and range) concentration and length of extracellular DNA in sputum samples from patients with cystic fibrosis

\begin{tabular}{|c|c|c|c|c|}
\hline & No. & No treatment with DNase & No. & Inhalation with DNase \\
\hline $\begin{array}{l}\text { All sputum samples: } \\
\text { DNA concentration }(\mathrm{mg} / \mathrm{ml} \text { sputum) } \\
\text { Median DNA length }(\mathrm{kbp})^{1}\end{array}$ & $\begin{array}{l}167 \\
159\end{array}$ & $\begin{array}{l}0.6(0.3-1 \cdot 2 ; 0.0-9 \cdot 5) \\
1.3(0.7-1.5 ; 0.3-3 \cdot 0)\end{array}$ & $\begin{array}{l}177 \\
164\end{array}$ & $\begin{array}{l}0.3(0 \cdot 1-0.9 ; 0 \cdot 0-4 \cdot 8) \\
0.4(0.3-0.6 ; 0 \cdot 1-14 \cdot 1)\end{array}$ \\
\hline $\begin{array}{l}\text { Day-to-day variation during 3-day collection periods } \\
\text { Mean DNA concentration (mg/ml sputum) } \\
\text { Variance of DNA concentration (mg/ml sputum) }{ }^{2}\end{array}$ & $\begin{array}{l}\text { (Hann } \\
25 \\
20\end{array}$ & $\begin{array}{l}\text { r) } \\
0 \cdot 7(0 \cdot 2-1 \cdot 0 ; 0 \cdot 0-2 \cdot 3) \\
0 \cdot 5(0 \cdot 4-1 \cdot 6 ; 0 \cdot 1-3 \cdot 3)\end{array}$ & $\begin{array}{l}25 \\
24\end{array}$ & $\begin{array}{l}0.4(0 \cdot 2-1 \cdot 0 ; 0 \cdot 0-2 \cdot 2) \\
0.5(0 \cdot 2-1 \cdot 2 ; 0 \cdot 1-3 \cdot 0)\end{array}$ \\
\hline
\end{tabular}

${ }^{1}$ Yield of purified DNA was too low in eight pretreatment and 13 treatment samples to perform densitometry of gel separated DNA.

${ }^{2}$ Variance was only calculated if patients delivered two $(2,1$ patients $)$ or three $(18,23$ patients) sputum containers.

The statistical significance of the impact of rhDNase inhalation on DNA length and concentration was evaluated with the Mann-Whitney rank test. Aliquots of cystic fibrosis sputum controls which were either immediately processed after collection or intermittently stored at $-20^{\circ} \mathrm{C}$ for up to eight weeks gave the same results within experimental error.

\section{Results}

The DNA contents in sputum samples from 132 patients were analysed before the first inhalation of rhDNase and from 129 patients after six weeks of inhalation of rhDNase. The extracellular DNA content in the sputum varied from 0 to $9.5 \mathrm{mg} / \mathrm{ml}$ (table). During inhalation with rhDNase the distribution of DNA concentration was significantly reduced $(p<0.005)$, the median concentration falling from 0.6 to $0.3 \mathrm{mg}$ extracellular $\mathrm{DNA} / \mathrm{ml}$ sputum (table). Samples collected from the same patient on consecutive days exhibited a broad variation of DNA content which is reflected by the fact that the mean and variance of specimens from individual patients covered a similar concentration range (table).

Extracellular DNA in the sputum was degraded to molecules of a few kilobase pairs (kbp) or less. Lanes 1 and 2 of the figure exhibit a typical example of the distribution of DNA length in the absence (lane 1) and presence (lane 2) of inhaled rhDNase. The small DNA size was not an experimental artefact due to

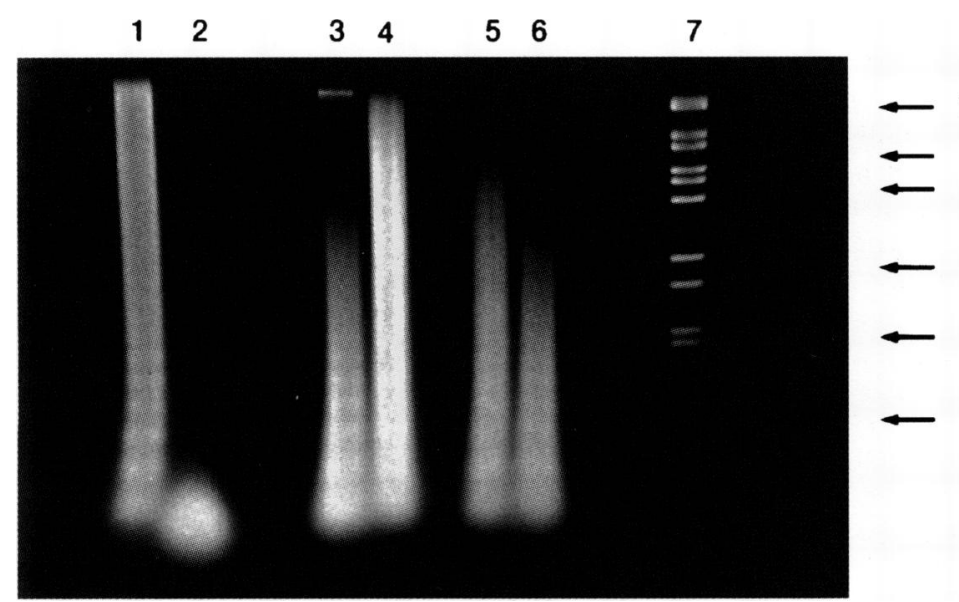

Ethidium bromide stain of gel separated extracellular DNA isolated from sputum before (left lanes) and during (right lanes) administration of aerosolised rhDNase from three patients with cystic fibrosis. Lanes 1 and 2 represent a typical example, while the samples separated in lanes $3 / 4$ and $5 / 6$ belong to the 18 non-responders. Lane $7=\lambda-B s t E I I$ digest as size marker. shearing because the isolation of DNA from peripheral blood cells processed in parallel by the same protocol yielded high molecular weight DNA with a median size of about $50 \mathrm{kbp}$. The median DNA length decreased significantly during inhalation with rhDNase $\left(\mathrm{p}<10^{-9} ;\right.$ table $)$. The median interquartile range of DNA length decreased from 0.5 to $2.6 \mathrm{kbp}$ before treatment with DNase to a smaller and narrower range of $0.3-1.0 \mathrm{kbp}$ during inhalation with rhDNase $\left(\mathrm{p}<10^{-9}\right)$. No reduction of DNA size during treatment was seen in samples from 18 patients $(13 \%$ of study population) of which two examples are shown in the figure (lanes 4 and 6).

\section{Discussion}

rhDNase was developed to reduce the contribution of high molecular weight DNA to the abnormal viscoelastic properties of bronchial secretions in patients with cystic fibrosis. We measured the length and content of extracellular DNA which should be the target of aerosolised rhDNase. To our knowledge, all data in the literature refer to the total amount of intracellular and extracellular DNA in cystic fibrosis secretions. Warren et al ${ }^{11}$ detected a mean DNA content of $10 \%$ of dry weight in bronchial secretions, whereas 20 years later Picot and colleagues ${ }^{12}$ found values of $1 \cdot 1 \%$ in mucoid, $1.9 \%$ in mucopurulent, and $3.6 \%$ in purulent cystic fibrosis sputum samples. The lower values in this latter report may reflect improvements in the treatment of the airways disease in patients with cystic fibrosis and, indeed, changes of the DNA content of sputum from average values of 5.9 to $2.6 \mathrm{mg} / \mathrm{ml}$ were observed in association with clinical manifestations and treatment. ${ }^{13} \mathrm{~A}$ comparison of the data in the literature with those in this study indicates that the extracellular DNA contributes about $10-20 \%$ to the DNA content in the sputum of patients with cystic fibrosis. The large day-to-day variation of the extracellular DNA content of the sputum of these patients is probably the result of the spatially uneven composition and mobilisation of secretions drained during physiotherapy.

Extracellular DNA in the sputum of patients with cystic fibrosis was regularly degraded, probably by nuclease activities released from shedded human cells into the secretions. DNA molecules of up to $1.5 \mathrm{kbp}$ in size are quasirodlike in solution, but the hydrodynamic behaviour of larger molecules is more like that of a coil. ${ }^{14}$ Since we observed a median DNA 
length of $1.3 \mathrm{kbp}$, rod-like and coil-like molecules were present in comparable quantities. Upon inhalation with DNase the extracellular DNA was further degraded to smaller polynucleotides whereby, on average, $>90 \%$ of molecules fell into the category of rod-like chains of low intrinsic viscosity. The reduction in molecular weight was observed in all but 18 patients, indicating that rhDNase was enzymatically active in vivo and adequately aerosolised and delivered to the secretions. A second encouraging finding is the twofold decrease of median DNA content during inhalation with rhDNase. A reduced load of extracellular DNA is a measure of endobronchiolar cell debris and suggests that rhDNase affects local inflammation which could contribute to the reduced risk of respiratory exacerbations. ${ }^{7}$

This study was performed in collaboration with the members of the "German Clinical Study Group on rhDNase" at the Roche company (Dr Deuber) and the cystic fibrosis clinics in Berlin (Dr Tacke), Essen (Dr Stephan), Frankfurt (Dr Posselt), Gießen (Dr Lindemann), Halle (Dr Brömme), Hannover (Dr Ballmann) and München (Drs Harms).

We are grateful to patients and parents for their participation and would like to thank our clinical colleagues for their organizational help.

1 Boat TF, Welsh MJ, Beaudet AL. Cystic fibrosis. In: Scriver $\mathrm{CR}$, Beaudet AL, Sly WS, Valle D, eds. The metabolic basis of inherited disease. 6th edn. New York: McGraw-Hill, 1989:2649-80

2 Shak S, Capon DJ, Hellmiss R, Marsters SA, Baker CL Recombinant human DNase I reduces the viscosity of cystic fibrosis sputum. Proc Natl Acad Sci USA 1990;87: 9188-92.

3 Aitken ML, Burke W, McDonald G, Shak S, Montgomery AB, Smith A. Recombinant human DNase inhalation in normal subjects and patients with cystic fibrosis: a phase 1 study. $\mathscr{F} A M A$ 1992;267:1947-51.

4 Hubbard RC, McElvaney NG, Birrer P, Shak S, Robinson WW, Jolley $\mathrm{C}$, et al. A preliminary study of aerosolized recombinant human deoxyribonuclease I in the treatment of cystic fibrosis. $N$ Engl $¥$ Med 1992;326:812-5.

5 Ramsey BW, Astley SJ, Aitken ML, Burke W, Colin AA, Dorkin HL, et al. Efficacy and safety of short-term adDorkin $\mathrm{HL}$, et al. Efficacy and safety of short-term ad-
ministration of aerosolized recombinant human deoxymibistration of aerosolized recombinant human deoxyribonuclease in patients

6 Ranasinha C, Assoufi B, Shak S, Christiansen D, Fuchs $\mathrm{H}$, Empey D, et al. Efficacy and safety of short-term administration of aerosolized human DNase I in adult with stable stage cystic fibrosis. Lancet 1993;342:199-202.

7 Fuchs HJ, Borowitz DS, Christiansen DH, Morris EM, Nash ML, Ramsey BW, et al. Effect of aerosolized recombinant human DNase on exacerbations of respiratory symptoms and on pulmonary function in patients with cystic fibrosis. N Engl $₹$ Med 1994;331:637-42.

8 Burton K. A study of the conditions and mechanism of the diphenylamine reaction for the colorimetric estimation of diphenylamine reaction for the colorimetric estimation
deoxyribonucleic acid. Biochem $f 1956 ; 62: 315-23$.

9 Croft DN, Lubran M. The estimation of DNA in the presence of sialic acid: application to analysis of human gastric washing. Biochem $\mathcal{F}$ 1965;95:612-20.

10 Gross-Bellard M, Dudet P, Chambon P. Isolation of highmolecular-weight DNA from mammalian cells. Eur $\mathfrak{f}$ Biochem 1973;36:32-38.

11 Warren S, Chernick D, Guilio JB. Composition of tracheobronchial secretions in cystic fibrosis of the pancreas and bronchiectasis. Pediatrics 1959;24:739-45.

12 Picot R, Das I, Reid L. Pus, deoxyribonucleic acid, and sputum viscosity. Thorax 1978;33:235-42.

13 Smith AL, Redding G, Doershuk C, Goldmann D, Gore E, Hilman B, et al. Sputum changes associated with therapy for endobronchial exacerbation in cystic fibrosis therapy for endobronchial

14 Cantor RC, Schimmel PR. Elementary polymer-chain hydrodynamics and chain dimensions. In: Biophysical chemistry: the behaviour of biological macromolecules. San Francisco: W H Freeman, 1980:1019-39. 